\title{
Corrigendum: Construction of SARS-CoV-2 Virus-Like Particles by Mammalian Expression System
}

\author{
Ruodan $X u^{1}$, Mingfei Shi ${ }^{1}$, Jing $\mathrm{Li}^{2}$, Ping Song ${ }^{3}$ and Ning $\mathrm{Li}^{{ }^{*}}$ \\ ${ }^{1}$ Institute of Basic Theory for Chinese Medicine, China Academy of Chinese Medical Sciences, Beijing, China, ${ }^{2}$ Dongzhimen \\ Hospital, Beijing University of Chinese Medicine, Beijing, China, ${ }^{3}$ Guang'anmen Hospital, China Academy of Chinese Medical \\ Sciences, Beijing, China
}

Keywords: COVID-19, SARS-CoV-2, virus-like particles, self-assemble, release

\section{A Corrigendum on}

Construction of SARS-CoV-2 Virus-Like Particles by Mammalian Expression System by Xu, R., Shi, M., Li, J., Song, P., and Li, N. (2020). Front. Bioeng. Biotechnol. 8:862. doi: 10.3389/fbioe.2020.00862

OPEN ACCESS

Approved by:

Frontiers Editorial Office,

Frontiers Media SA, Switzerland

*Correspondence:

Ning Li

lili.li.ning@gmail.com

Specialty section: This article was submitted to Biomaterials,

a section of the journa Frontiers in Bioengineering and

Biotechnology

Received: 04 August 2020

Accepted: 05 August 2020

Published: 09 September 2020

Citation:

Xu R, Shi M, Li J, Song P and Li N (2020) Corrigendum: Construction of SARS-CoV-2 Virus-Like Particles by Mammalian Expression System.

Front. Bioeng. Biotechnol. 8:1026. doi: 10.3389/fbioe.2020.01026
In the original article, there was an error in the Materials and Methods section, subsection Plasmid Construction and Molecular Cloning. The section should read as follows:

Human codon optimized sequences of genes encoding $\mathrm{S}, \mathrm{M}, \mathrm{E}$ and $\mathrm{N}$ structural proteins of SARS-CoV-2 with C-terminal FLAG tag (peptide sequence: DYKDDDDK) were synthesized by Genscript Biotechnology (Nanjing, China): the major structural S glycoprotein (Gen Bank: QHD43416.1), E protein (Gen Bank: QHD43418.1), M protein (Gen Bank: QHD43419.1) and N protein (Gen Bank: QHD43423.2). NheI and NotI (NEB, England BiolLabs, Beverly, MA, United States) restriction sites were placed at $5^{\prime}$ and $3^{\prime}$ ends, respectively. The four genes were cloned into the double NheI and NotI restriction sites of the expression vector pcDNA3.1. Then the transformation experiments were performed with chemically competent cells DH5 $\alpha$ (TransGen Biotechnology, Beijing, China) using the heat shock method in the water bath at $42^{\circ} \mathrm{C}$ for $1 \mathrm{~min}$, followed by shaking at $37^{\circ} \mathrm{C}$ for $45 \mathrm{~min}$. After centrifugation at $2,800 \times \mathrm{g}$ for $3 \mathrm{~min}$, the transformed cells were plated on LB plates containing $50 \mu \mathrm{g} / \mathrm{ml}$ ampicillin and the plates were inverted and incubated at $37^{\circ} \mathrm{C}$ overnight. The resistant single colony was picked and amplified in LB medium. The correct orientation of the insertions was examined by restriction enzyme analysis and the open reading frames of recombinant plasmids were verified by DNA sequencing.

The authors apologize for this error and state that this does not change the scientific conclusions of the article in any way. The original article has been updated.

Copyright $\odot 2020 \mathrm{Xu}$, Shi, Li, Song and Li. This is an open-access article distributed under the terms of the Creative Commons Attribution License (CC BY). The use, distribution or reproduction in other forums is permitted, provided the original author(s) and the copyright owner(s) are credited and that the original publication in this journal is cited, in accordance with accepted academic practice. No use, distribution or reproduction is permitted which does not comply with these terms. 